\title{
KUALITAS PRODUK, CITRA MEREK DAN PERSEPSI HARGA TERHADAP PROSES KEPUTUSAN PEMBELIAN KONSUMEN SEPEDA MOTOR MATIC "HONDA"
}

\author{
Nurul Fatmawati. A \\ Euis Soliha \\ Program Studi Manajemen Fakultas Ekonomika dan Bisnis \\ Universitas Stikubank
}

Email: soliha.evis@gmail.com

\begin{abstract}
The purpose of this study was to analyze the effect of product quality, brand image and perception of the price of the consumer buying decision process matic Honda motorcycles. The population in this study were matic Honda motorcycle users. The samples in this study using purposive sampling, which means that sample based on specific criteria, namely: those who are older and those who use and have matic Honda motorcycles. The analytical tool used is multiple linear regression analysis. The results of the analysis can be concluded that: product quality, positive influence on consumer buying decision process matic Honda motorcycles. Brand image positive influence on consumer buying decision process matic Honda motorcycles. Perception price positive influence on consumer buying decision process matic Honda motorcycles.
\end{abstract}

Keywords: product quality, brand image, perception of price and consumer purchase decision process 


\section{Nurul Fatmawati. A \\ Euis Soliha}

\section{PENDAHULUAN}

Pada saat ini kebutuhan sepeda motor bagi masyarakat menjadi hal yang sangat penting mengingat tingginya kemacetan yang ada di jalan raya, menjadi salah satu alternatif untuk mempermudah dan kelancaran untuk mencapai suatu tujuan di dalam kota.Permintaan masyarakat terhadap sepeda motor terus mengalami peningkatan, hal ini memberikan peluang bagi para produsen sepeda motor untuk melakukan inovasi dari produk yang dihasilkannya. Ketertarikan pemilihan merek tersebut karena produk sepeda motor merek Honda semakinbanyak diminati oleh kalangan masyarakat. Gaya hidup modern merupakan salah satu faktor individu yang dapat mempengaruhi perilaku pembelian seseorang.

Pertumbuhan konsumen sepeda motor meningkat luar biasa. Di tengah-tengah persaingan yang begitu tajam akibat banyaknya merek pendatang baru, sepeda motor Honda yang sudah lama berada di Indonesia dengan segala keunggulannya, tetap mendominasi pasar dan sekaligus memenuhi kebutuhan angkutan yang tangguh, irit dan ekonomis. Menjawab tantangan tersebut, organisasi yang berada di balik kesuksesan sepeda motor Honda di Indonesia terus memperkuat diri.

Keunggulan tekhnologi motor Honda diakui di seluruh dunia dan telah dibuktikan dalam berbagai kesempatan. Honda pun mengembangkan tekhnologi yang mampu menjawab kebutuhan pelanggan yaitu mesin "bandel" dan irit bahan bakar, sehingga menjadikannya sebagai pelapor kendaraan roda dua yang ekonomis

Untuk memperkuat market share di pasar motor matic, PT. Astra Honda Motor meluncurkan produk matic yaitu Honda Vario 125, Vario 110 CW, Beat, Spacy dan Honda Scoopy. Dengan inovasi dan tekhnologi yang telah diperbaharui untuk produk motor ini, pihak Honda antusias untuk meluncurkan produk yang diperkirakan akan laris dalam pasar penjualan sepeda motor matic. Dengan mengandalkan slogannya "Motor Matic Gaul dan Irit" Honda matic diharapkan mampu memenuhi kebutuhan seluruh anggota keluarga tanpa melupakan unsur ekonomis (hemat bbm dan perawatan) yang sudah menjadi positioning sepeda motor Honda. Walaupun bukan motor khusus wanita pertama di Indonesia dan juga bukan cuma mencoba membidik motor khusus untuk gender cewek tetapi, juga dapat membuat banyak lelaki jatuh cinta pada motor ini.

Keputusan pembelian adalah sebuah pendekatan penyelesaian masalah pada kegiatan manusia untuk membeli suatu barang atau jasa dalam memenuhi keinginan dan kebutuhannya yang terdiri dari pengenalan kebutuhan dan keinginan, pencarian informasi 


\section{Jurnal Manajemen Teori dan Terapan \\ Tahun 10. No. 1, April 2017}

evaluasi terhadap alternatif pembelian, keputusan pembelian, dan tingkah laku setelah pembelian (Swasta dan Handoko 2000). Sedangkan menurut Kotlerdan Keller (2009) keputusan pembelian adalah suatu proses penyelesaian masalah yang terdiri dari menganalisa atau pengenalan kebutuhan dan keinginan, pencarian informasi, penilaian sumber-sumber seleksi terhadap alternatif pembelian, keputusan pembelian dan perilaku setelah pembelian.

Kualitas produk merupakan pengertian kualitas yang berpusat pada konsumen sehingga dapat dikatakan bahwa seorang penjual telah memberikan kualitas bila produk atau pelayanan penjual telah memenuhi atau melebihi harapan konsumen. Kualitas produk merupakan pemahaman bahwa produk yang ditawarkan oleh penjual mempunyai nilai jual lebih yang tidak dimiliki oleh produk pesaing. Akan tetapi, suatu produk dengan penampilan terbaik atau bahkan dengan tampilan lebih baik bukanlah merupakan produk dengan kualitas tinggi jika tambilannya bukanlah yang dibutuhkan dan diinginkan oleh pasar. Produk adalah segala segala sesuatu yang dapat ditawarkan produsen untuk diperhatikan, dicari, dibeli, digunakan atau dikonsumsi pasar sebagai pemenuhan kebutuhan atau keinginan pasar yang bersangkutan (Tjiptono 2008).

Citra merek merupakan segala hal yang terkait dengan merek yang ada dibenak konsumen atau kesan konsumen tentang suatu merek (Suryani 2013). Citra terhadap merek berhubungan dengan sikap yang berupa keyakinan dan preferensi terhadap suatu merek. Konsumen yang memiliki citra positif terhadap suatu merek, akan lebih memungkinkan untuk melakukan pembelian. Citra tidak dapat ditanamkan dalam pikiran konsumen dalam semalam atau disebarkan melalui satu media saja. Sebaliknya citra tersebut harus disampaikan melalui tiap sarana komunikasi yang tersedia dan disebarkan secara terus menerus karna tanpa citra yang kuat sangatlah sulit bagi sebuah perusahaan untuk menarik pelanggan baru dan mempertahankan pelanggan yang sudah ada. Penciptaan kesan menjadi salah satu karakteristik dasar dalam orientasi pemasaran modern, yaitu lewat pemberian perhatian lebih serta penciptaan merek yang kuat. Implikasi dari hal tersebut menjadikan merek suatu produk menciptakan image dari produk itu sendiri dari benak konsumen dan menjadikan motivasi dasar bagi konsumen dalam memilih suatu produk.

Persepsi harga adalah kecenderungan konsumen untuk menggunakan harga dalam memberi penilaian tentang kualitas produk (Burton et al. 1998, Sinha and Batra 1999-2000, Garretson et al. 2002 dalam Fransiska 2010). Kotler \& Keller (2009), persepsi adalah proses yang digunakan oleh individu untuk memilih, mengorganisasi, dan menginterpretasi masukan informasi guna menciptakan gambaran dunia yang memiliki arti. Salah satu sektor-sektor 


\section{Nurul Fatmawati. A \\ Euis Soliha}

yang berpengaruh terhadap persepsi pelanggan adalah harga. Perusahaan dapat menetapkan harga tinggi untuk membentuk persepsi produk tersebut berkualitas. Sementara itu, harga rendah dapat membentuk persepsi pembeli tidak percaya pada penjual karna meragukan kualitas produk atau pelayanannya. Seperti yang dikemukakan oleh Stanton (2004) adalah sejumlah uang (kemungkinan ditambah barang) yang ditentukan untuk memperleh beberapa kombinasi sebuah produk dan pelanggan yang menyertainya. Harga mempengaruhi tingkat penjualan, tingkat keuntungan market share yang dapat dicapai oleh perusahaan.

Penelitian yang dilakukan oleh Andrianto (2013) dengan hasil bahwa kualitas produk, citra merek, harga dan promosi berpengaruh positif terhadap keputusan pembelian, penelitian yang dilakukan oleh IryanitadanSugiarto(2013), dengan hasil bahwa citra merek, persepsi harga dan persepsi kualitas produk berpengaruh positif terhadap keputusan pembelian danPurwati dkk (2012) dengan hasil bahwa harga dan kualitas produk berpengaruh positif terhadap keputusan pembelian.

Berdasarkan hal tersebut, maka analisis mengenai keputusan pembelian sangat penting dilakukan oleh perusahaan-perusahaan yang memasarkan produk sepeda motor. Hal tersebut perlu dilakukan agar perusahaan dapat selalu meningkatkan volume penjualan yaitu melalui analisa faktor atau atribut apa saja yang menjadi pertimbangan konsumen dalam membeli sepeda motor. Karena sesungguhnya masing-masing konsumen tentu memiliki motif yang berbeda dalam melakukan pembelian sepeda motor.

Berdasarkan uraian dan latar belakang masalah dalam penelitian ini, maka dapat ditarik pertanyaan penelitian "Bagaimana pengaruh kualitas produk, citra merek dan persepsi harga terhadap proses keputusan pembelian konsumen Sepeda Motor Matic Honda?

Tujuan dalam penelitian ini adalah untuk menguji dan menganalisis pengaruh kualitas produk, citra merek dan persepsi harga terhadap proses keputusan pembelian konsumen Sepeda Motor Matic Honda.

\section{KERANGKA TEORITIS DAN PENGEMBANGAN HIPOTESIS}

\section{Proses Keputusan Pembelian}

Pengambilan keputusan merupakan pekerjaan sehari-hari dalam manajemen sehingga kita perlu mengetahui apakah pengambilan keputusan itu, bagaimana kita tiba pada keputusan, apa keputusan itu, tingkat-tingkat klasifikasinya, dan jenis-jenisnya. Selain itu, perlu pula diketahui teknik pengambilan keputusan, pendekatan metodenya, teori-teorinya, etika 


\section{Jurnal Manajemen Teori dan Terapan \\ Tahun 10. No. 1, April 2017}

dalam pengambilan keputusan, peranan birokrasi dalam pengambilan keputusan dan hubungan antara pengambilan keputusan dan penyelesaian masalah.

Keputusan (decision) berarti pilihan (choice), yaitu pilihan dari dua atau lebih kemungkinan. Namun, hampir tidak merupakan pilihan antara yang benar dan yang salah, tetapi yang justru sering terjadi ialah pilihan antara yang "hampir benar" dan yang "mungkin salah". Walaupun keputusan biasa dikatakan sama dengan pilihan, ada perbedaan penting di antara keduanya. Keputusan adalah "pilihan nyata" karena pilihan diartikan sebagai pilihan tentang tujuan termasuk pilihan tentang cara untuk mencapai tujuan itu, apakah pada tingkat perorangan atau pada tingkat kolektif. Keputusan kaitannya dengan proses merupakan keadaan akhir dari suatu proses yang lebih dinamis, yang diberi label pengambilan keputusan. Keputusan dipandang sebagai proses karena terdiri atas satu seri aktivitas yang berkaitan dan tidak hanya dianggap sebagai tindakan bijaksana.

Machfoedz (2005) mengemukakan bahwa pengambilan keputusan adalah suatu proses penilaian dan pemilihan dari berbagai alternatif sesuai dengan kepentingan-kepentingan tertentu dengan menetapkan suatu pilihan yang dianggap paling menguntungkan. Proses penilaian itu biasanya diawali dengan mengindentifikasi masalah utama yang mempengaruhi tujuan, menyusun, menganalisis, dan memilih berbagai alternatif tersebut dan mengambil keputusan yang dianggap paling baik. Langkah terakhir dari proses itu merupakan sistim evaluasi untuk menentukan efektifitas dari keputusan yang telah diambil.

Menurut Kotler (2000) proses pengambilan keputusan pembelian terdiri dari lima tahap: pengenalan kebutuhan, pencarian informasi, pengevaluasian alternatif, keputusan pembelian, dan perilaku setelah pembelian. Adapun tahapan-tahapan tersebut dapat digambarkan sebagai berikut:

a. Pengenalan Masalah

Proses dimulai saat pembeli menyadari adanya masalah atau kebutuhan. Pembeli merasakan adanya perbedaan antara yang nyata dan yang diinginkan. Kebutuhan ini disebabkan karena adanya rangsangan internal maupun eksternal.

b. Pencarian Informasi

Seorang konsumen yang terdorong kebutuhannya mungkin, atau mungkin juga tidak, mencari informasi lebih lanjut. Jika dorongan konsumen kuat dan produk itu berada di dekatnya, mungkin konsumen akan langsung membelinya. Jika tidak, kebutuhan konsumen ini hanya akan menjadi ingatan saja.

c. Evaluasi Alternatif 


\section{Nurul Fatmawati. A \\ Euis Soliha}

Konsumen memproses informasi tentang pilihan merek untuk membuat keputusan terakhir. Pertama, kita melihat bahwa konsumen mempunyai kebutuhan. Konsumen akan mencari manfaat tertentu dan selanjutnya melihat kepada atribut produk. Konsumen akan memberikan bobot yang berbeda untuk setiap atribut produk sesuai dengan kepentingannya.

d. Keputusan Pembelian

Pada tahap evaluasi, konsumen menyusun merek-merek dalam himpunan pilihan serta membentuk niat pembelian. Biasanya ia akan memilih merek yang disukai. Tetapi ada pula faktor yang mempengaruhi seperti sikap orang lain dan faktor-faktor keadaan yang tidak terduga.

e. Perilaku Sesudah Pembelian

Sesudah pembelian terhadap suatu produk, konsumen akan mengalami beberapa tingkat kepuasan atau ketidakpuasan.

\section{Kualitas Produk}

Kotler dan Armstrong (2008) bahwa kualitas produk adalah salah satu faktor yang paling diandalkan olehseorang pemasar dalam memasarkan suatu produk. Oentoro (2010) kualitas produk adalah hal yang perlu mendapat perhatian utama dariperusahaan atau produsen, mengingat kualitas suatu produk berkaitan eratdengan kepuasan konsumen, yang merupakan tujuan dari kegiatan pemasaran yang dilakukan perusahaan. Dapat disimpulkan kualitas produk adalah suatu kondisi dinamis yang saling berhubungan meskipun dapat memiliki definisi yang berbeda tetapi produk pada intinya memiliki suatu spesifikasi terhadap suatu barang atau jasa yang dapat menimbulkan kepuasan yang memenuhi atau melebihi harapan bagi konsumen yang menggunakannya.

Menurut Stanton (2004), artinya suatu produk adalah kumpulan dari atribut atribut yangnyata maupun tidak nyata, termasuk di dalamnya kemasan, warna, harga, kualitas dan merk ditambahdengan jasa dan reputasi penjualannya.Menurut Tjiptono (1999) secara konseptual produk adalah pemahaman subyektif dariprodusen atas "sesuatu" yang bisa ditawarkan sebagai usaha untuk mencapai tujuan organisasi melaluipemenuhan kebutuhan dan keinginan konsumen, sesuai dengan kompetensi dan kapasitas organisasiserta daya beli.

Menurut Kotler (2000) mengungkapkan ada tujuh dimensi kualitas produk, yaitu :

1. Performance (kinerja), Kinerja merupakan karakteristik atau fungsi utama suatu produk. Ini manfaat atau khasiat utama produk yang kita beli. Biasanya ini menjadi pertimbangan pertama kita dalam membeli suatu produk.

2. Feature (keistimewaan), Sebagian besar produk dapat ditawarkan dengan berbagai keistimewaan seperti karakteristik yang melengkapi fungsi dasar produk 


\section{Jurnal Manajemen Teori dan Terapan \\ Tahun 10. No. 1, April 2017}

3. Realibility(kehandalan), Ukuran kemungkinan sebuah proyek tak akan rusak atau gagal dalam suatu periode tertentu. Pembeli pada umumnya akan membayar lebih demi mendapatkan suatu produk yang diandalkan

4. Conformance (mutu kinerja), Mutu kinerja mengacu pada level dimana karakteristik dasar produk itu beroperasi. Sebagian besar produk ditetapkan pada level kerja, yaitu : rendah, rata-rata, tinggi, dan super.

5. Durability (daya tahan), Suatu ukuran operasi yang diharapkan dalam kondisi normal atau berat. Daya tahan merupakan atribut berharga dalam menawarkan sebuah produk

6. Serviceability(pelayanan), Karakteristik yang berkaitan dengan kecepatan kompetensi, kemudahan dan akurasi dalam memberikan pelayanan untuk perbaikan barang

7. Estetika (keindahan / gaya), Merupakan karakteristik yang subjektif mengenai nilai-nilai estetika yang berkaitan dengan pertimbangan pribadi dan refleksi serta prefensi individu.

Para peminat beli pelanggan potensial menginginkan agar produk harus dibuat berkualitas, terutama dalam memenuhi harapan konsumen agar menjadi puas dan loyal pada perusahaan. Kotler dan Amstrong (2008) mengemukakan bahwa: Kualitas produk adalah kemampuan suatu produk untuk melaksanakan fungsinya, meliputi kehandalan, daya tahan, ketepatan, kemudahan operasi, dan perbaikan produk, serta atribut bernilai lainnya. Setiap perusahaan yang menginginkan dapat memenuhi kebutuhan dan keinginan pelanggan, maka akan berusaha membuat produk yang berkualitas, yang ditampilkan baik melalui ciriciri luar (design) produk maupun inti (core) produk itu sendiri.Kotler \& Amstrong (2008) kualitas produk adalah salah satu sarana positioning utama pemasar. Kualitas mempunyai dampak langsung pada kinerja produk atau jasa, oleh karna itu kualitas berhubungan erat dengan nilai dan kepuasan pelanggan. Dalam arti yang lebih sempit, kualitas bisa didefinisikan sebagai "bebas dari kerusakan". Tetapi sebagaian perusahaan yang berpusat pada pelanggan melangkah jauh melampaui definisi sempit ini.justrumereka mendefinisikan kualitas berdasarkan penciptaan nilai dan kepuasan pelanggan.

\section{Citra Merek}

Citra merekadalah asosiasi atau persepsi konsumen berdasarkan ingatan mereka terhadap suatu produk. Brand image (citra merek) tidak terdapat dalam fitur, teknologi atau jenis produk itu sendiri, citra timbul karena iklan, promosi, atau penggunanya. Melalui citra merek, konsumen dapat mengenali produk, mengevaluasi kualitas, mengurangi risiko pembelian, dan memperoleh pengalaman tertentu serta mendapatkan kepuasan tertentu dari suatu produk (Keller 1993) dalam Lin (2007). Brand image atau brand description, yakni deskripsi tentang asosiasi dan keyakinan terhadap merek tertentu. Brand Image dapat dianggap sebagai jenis asosiasi yang muncul dalam benak konsumen ketika mengingat suatu merek 


\section{Nurul Fatmawati. A \\ Euis Soliha}

tertentu. Asosiasi itu dapat muncul dalam bentuk citra atau pemikiran tertentu yang dikaitkan dengan suatu merek (Tjiptono 2005). Jenis asosiasi merek meliputi atribut, manfaat dan sikap. Atribut terdiri dari atribut yang berhubungan dengan produk misalnya desain, warna, ukuran, dan atribut yang tidak berhubungan dengan produk, misalnya harga, pemakai, dan citra penggunaan. Sedangkan manfaat mencakup manfaat secara fungsional, manfaat simbolis dan manfaat berdasarkan pengalaman (Shimp, 2003). Indikator untuk variabel brand image yaitu :

a. Recognition, Tingkat dikenalnya sebuah brand oleh konsumen (pengakuan/pengenalan)

b. Reputation, Tingkat atau status yang cukup tinggi bagi sebuah merek(brand) karna lebih terbukti mempunyai track record yang baik (Nama/ Logo)

c. Affinity Royalty, Hubungan emosional yang terjadi antar (brand) dengan konsumennya (ketertarikan)

Baik Keller dan Aaker mengemukakan bahwa adanya hubungan yang erat diantara asosiasi merek dengan citra merek dimana asosiasi yang terjalin pada suatu merek dapat membentuk citra merek. Asosiasi merek dapat membantu proses mengingat kembali informasi yang berkaitan dengan produk, khususnya selama proses pembuatan keputusan untuk melakukan pembelian. Jadi, antara citra merek dan asosiasi merek mempunyai keterkaitan yang erat yang tidak terpisahkan satu dengan yang lainya.

Citra merupakan keseluruhan persepsi terhadap produk atau merek yangdibentuk dari informasi dan pengalaman masa lalu terhadap produk atau merek itu(Sutisna 2003). Suatu citra merek yang kuat dapat memberikan beberapakeunggulan utama bagi suatu perusahaan salah satunya akan menciptakan suatukeunggulan bersaing. Produk yang memilki citra merek yang baik cenderung akanlebih mudah diterima oleh konsumen. Citra terhadap produk berhubungan dengansikap yang berupa keyakinan dan preferensi terhadap suatu produk. Konsumendengan citra positif terhadap suatu produk, lebih memungkinkan untuk melakukanpembelian, oleh karena itu kegunaan utama dari iklan diantaranya adalah untukmembangun citra positif terhadap suatu produk. Manfaat lain dari citra produkyang positif, yaitu dengan mengembangkan suatu produk dan memanfaatkan citrapositif yang telah terbentuk terhadap produk lama (Sutisna 2003). Semakinbaik citra suatu merek, semakin tinggi keputusan konsumen untuk melakukan pembelian.

\section{Persepsi Harga}

Persepsi harga (price perception) adalah nilai yang terkandung dalam suatu harga yang berhubungan dengan manfaat dan memiliki atau menggunakan suatu produk atau jasa (Kotler dan Amstrong 2008). Menurut Peter \& Olson (2008) berpendapat bahwa harga dapat 
menggambarkan suatu merek dan memberikan keunggulan kompetitif fungsional. Dalam menggambarkan merek, harga tinggi dapat diketahui berkualitas tinggi untuk beberapa produk dan sering dinyatakan bahwa konsumen merasakan hubungan antar harga dan kualitas.

Persepsi atas harga menyangkut bagaimana informasi harga dipahami oleh konsumen dan dibuat bermakna bagi mereka. Dalam pengolahan kognitif informasi harga, konsumen bisa membandingkan antara harga yang dinyatakan dengan sebuah harga atau kisaran harga yang mereka bayangkan atas produk tersebut .harga yang ada dipikiran sebagai bahan melakukan perbandingan tersebut disebut harga acuan internal. Harga acuan internal adalah harga yang dianggap pantas oleh konsumen, harga yang telah ada secara historis atau yang dibayangkan konsumen sebagai harga pasar yang tinggi atau rendah.pada dasarnya harga acuan internal menjadi semacam panduan untuk mengevaluasi apakah harga yang tertera tersebut dapat diterima oleh konsumen (Peter \& Olson 2008).

\section{Pengembangan Hipotesis}

\section{Hubungan Kualitas Produk Terhadap Proses Keputusan Pembelian}

Kualitas produk menurut Feigenbaum (2000) bahwa kualitas produk adalah keseluruhan gabungan karakteristik barang dan jasa dari pemasaran, rekayasa, pembuatan dan pemeliharaan yang memuat produk dan jasa yang digunakan memenuhi harapan pelanggankualitas produk terhadap keputusan pembelian

Berdasarkan hasil penelitian yang dilakukan oleh Iryanita dan Sugiarto (2013), Saidani (2013) menyimpulkan bahwa variabel kualitas produk berpengaruh positif terhadap keputusan pembelian.Maka dari itu dinyatakan bahwa agar perusahaan untuk lebih memberikan focuspada kualitas produk dan membandingkan dengan produk pesaing. Karena semakin tinggi kualitas produk maka konsumen akan mengambil keputusan pembelian.Berdasarkan dari asumsi tersebut maka dalam penelitian ini dapat disimpulkan hipotesis:

\section{$H_{1}$ : $\quad$ kualitas produk berpengaruh positif terhadap proses keputusan pembelian}

\section{Hubungan Citra Merek terhadap Proses Keputusan Pembelian}

Brand image atau brand description, yakni deskripsi tentang asosiasi dan keyakinan terhadap merek tertentu. Brand Image dapat dianggap sebagai jenis asosiasi yang muncul dalam benak konsumen ketika mengingat suatu merek tertentu. Asosiasi itu dapat muncul dalam bentuk citra atau pemikiran tertentu yang dikaitkan dengan suatu merek (Tjiptono 2005) 


\section{Nurul Fatmawati. A}

\section{Euis Soliha}

Berdasarkan hasil penelitian yang dilakukan oleh Iryanita dan Sugiarto (2013), Adrianto (2013) menyimpulkan bahwa variabel citra merek berpengaruh positif terhadap keputusan pembelian.Brand image yang positif akan membuat konsumen menyukai produk dengan merek yang bersangkutan bagi produsen, brand image yang baik akan membantu kegiatan perusahaan dalam bidang pemasaran, maka dari itu selain memperhatikan atribut fisik dari produknya, tugas perusahaan adalah membangun citra merek yang positif agar tingkat permintaan pembelian terhadap produknya semakin meningkat

Berdasarkan dari asumsi tersebut maka dalam penelitian ini dapat disimpulkan hipotesis :

\section{$\mathrm{H}_{2}$ : Citra merek berpengaruh positif terhadap proseskeputusan pembelian}

\section{Hubungan Persepsi Harga terhadap Proses Keputusan Pembelian}

Peter dan Olson (2008) menyatakan: persepsi harga berkaitan dengan bagaimana informasi harga dipahami seluruhnya oleh konsumen dan memberikan makna yang dalam bagi mereka. Pada saat konsumen melakukan evaluasi dan penelitian terhadap harga dari suatu produk sangat dipengaruhi oleh perilaku dari konsumen itu sendiri.

Persepsi harga sering kali menjadi sasaran investigasi dalam suatu penelitian, dibandingkan dengan objective price. Sebab, konsumen biasanya tidak mengevaluasi harga pasti (exact price) dari suatu produk ketika hendak melakukan pembelian, namun mereka mempersepsikan harga produk tersebut sebagai suatu harga yang murah, masuk akal (reasonable), atau mahal berdasarkan internal reference price mereka (Zeithaml, 1988). Semakin baik persepsi konsumen terhadap harga, maka akan meningkatkan keputusan pembelian.

Penelitian yang telah dilakukan oleh Iryanita dan Sugiarto (2013), menyimpulkan bahwa persepsi harga berpengaruh positif terhadap keputusan pembelian. Berdasarkan dari asumsi tersebut maka dalam penelitian ini dapat disimpulkan hipotesis :

\section{$\mathrm{H}_{3}$ : $\quad$ Persepsi harga berpengaruh positif terhadap proses keputusan pembelian}

\section{METODE PENELITIAN}

\section{Populasi dan Sampel}


Populasi dalam penelitian ini adalah pengguna sepeda motor matic Honda.Sampel dalam penelitian ini adalah konsumen pengguna sepeda motor matic Honda di wilaayah Puri Anjasmoro.

Penentuan sampel dalam penelitian ini menggunakan non probability sampling dengan metode pengambilan sampel yang digunakan adalah purposive sampling, yaitu yaitu pengambilan sampel berdasarkan kriteria tertentu, yaitu: orang yang sudah dewasa dan orang yang menggunakan dan memiliki sepeda motor matic Honda.

Definisi Operasional dan Pengukuran Variabel

Tabel1

Definisi Operasional dan Pengukuran Variabel

\begin{tabular}{|c|c|c|c|c|}
\hline No & $\begin{array}{c}\text { Nama } \\
\text { variabel }\end{array}$ & Definisi konsep & $\begin{array}{l}\text { Definisi operasional } \\
\text { (indikator) }\end{array}$ & $\begin{array}{c}\text { Skala } \\
\text { pengukuran }\end{array}$ \\
\hline 1 & $\begin{array}{l}\text { Kualitas } \\
\text { produk }\end{array}$ & 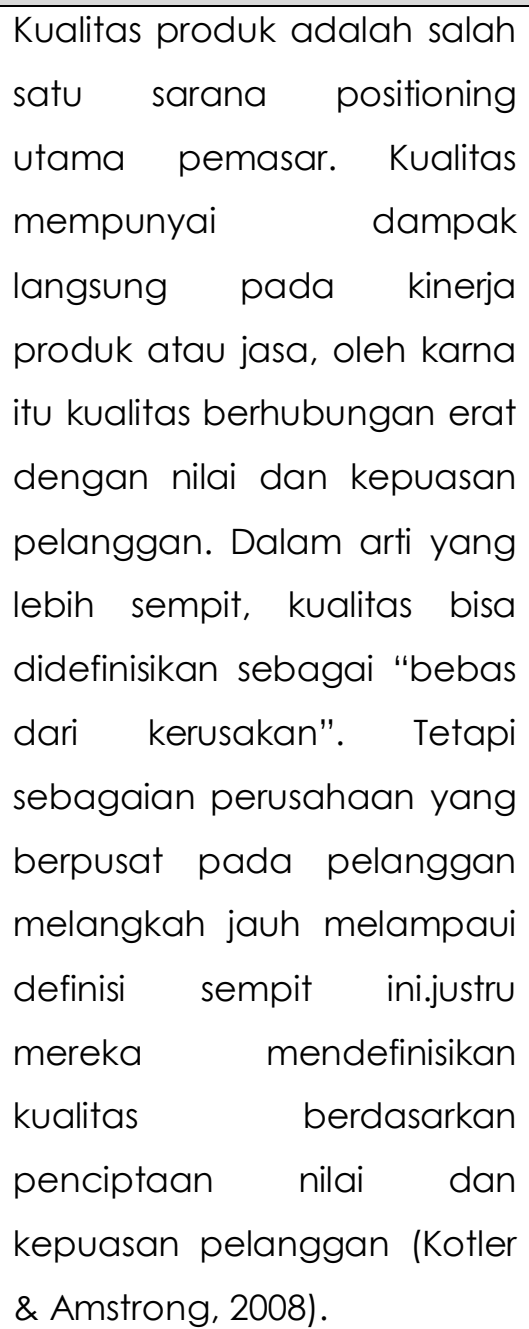 & $\begin{array}{l}\text { a. Kinerja } \\
\text { b. Fitur } \\
\text { c. Kehandalan } \\
\text { d. Mutu kerja } \\
\text { e. Daya tahan } \\
\text { f. Pelayanan } \\
\text { g. Keindahan }\end{array}$ & $\begin{array}{l}\text { 5kategori } \\
\text { jawaban: } \\
\text { 1. Sangat } \\
\text { tidak } \\
\text { setuju } \\
\text { 2. Tidak } \\
\text { setuju } \\
\text { 3. Netral } \\
\text { 4. Setuju } \\
\text { 5. Sangat } \\
\text { setuju }\end{array}$ \\
\hline 2 & Citra & Brand image atau brand & a. Pengenalan & 5kategori \\
\hline
\end{tabular}


Nurul Fatmawati. A

\section{Euis Soliha}

\begin{tabular}{|c|c|c|c|c|}
\hline & merek & $\begin{array}{l}\text { description, yakni deskripsi } \\
\text { tentang asosiasi dan } \\
\text { keyakinan terhadap merek } \\
\text { tertentu. Brand Image dapat } \\
\text { dianggap sebagai jenis } \\
\text { asosiasi yang muncul dalam } \\
\text { benak konsumen ketika } \\
\text { mengingat suatu merek } \\
\text { tertentu. Asosiasi itu dapat } \\
\text { muncul dalam bentuk citra } \\
\text { atau pemikiran tertentu yang } \\
\text { dikaitkan dengan suatu } \\
\text { merek (Tjiptono, 2005). }\end{array}$ & $\begin{array}{l}\text { b. Nama/logo } \\
\text { c. ketertarikan }\end{array}$ & $\begin{array}{l}\text { jawaban: } \\
\text { 1. Sangat } \\
\text { tidak } \\
\text { setuju } \\
\text { 2. Tidak } \\
\text { setuju } \\
\text { 3. Netral } \\
\text { 4. Setuju } \\
\text { 5. Sangat } \\
\text { setuju }\end{array}$ \\
\hline 3 & $\begin{array}{l}\text { Persepsi } \\
\text { harga }\end{array}$ & $\begin{array}{l}\text { Persepsi atas harga } \\
\text { menyangkut bagaimana } \\
\text { informasi harga dipahami } \\
\text { oleh konsumen dan dibuat } \\
\text { bermakna bagi mereka. } \\
\text { (Peter \& Olson 2014) }\end{array}$ & $\begin{array}{l}\text { a. Kesesuaian harga } \\
\text { dengan kualitas } \\
\text { produk } \\
\text { b.Perbandingan harga } \\
\text { dengan pesaing } \\
\text { c. Jumlah vang yang } \\
\text { dimiliki }\end{array}$ & $\begin{array}{l}\text { 5kategori } \\
\text { jawaban: } \\
\text { 1. Sangat } \\
\text { tidak } \\
\text { setuju } \\
\text { 2. Tidak } \\
\text { setuju } \\
\text { 3. Netral } \\
\text { 4. Setuju } \\
\text { 5. Sangat } \\
\text { setuju }\end{array}$ \\
\hline 4 & $\begin{array}{l}\text { Proses } \\
\text { Keputusa } \\
\mathrm{n} \\
\text { pembeli } \\
\text { an }\end{array}$ & $\begin{array}{l}\text { Menurut Kotler (2000) proses } \\
\text { pengambilan keputusan } \\
\text { pembelian terdiri dari lima } \\
\text { tahap: } \\
\text { kebutuhan, pengenalan } \\
\text { informasi, pengevaluasian } \\
\text { alternatif, keputusan } \\
\text { pembelian, dan perilaku } \\
\text { setelah pembelian. }\end{array}$ & $\begin{array}{l}\text { a.untuk menunjang } \\
\text { kegiatan sehari-hari } \\
\text { b.mendapat informasi } \\
\text { dari teman, media } \\
\text { cetak dan elektronik } \\
\text { c.membeli setelah me- } \\
\text { ngevaluasi merek lain } \\
\text { d.membeli karenasu- } \\
\text { dah mantap \& tidak } \\
\text { ragu-ragu } \\
\text { e.Secara keseluruhan, } \\
\text { puas dengansepeda } \\
\text { motor matic honda }\end{array}$ & $\begin{array}{l}\text { 5kategori } \\
\text { jawaban : } \\
\text { 1. Sangat } \\
\text { tidak } \\
\text { setuju } \\
\text { 2. Tidak } \\
\text { setuju } \\
\text { 3. Netral } \\
\text { 4. Setuju } \\
\text { 5. Sangat }\end{array}$ \\
\hline
\end{tabular}




\section{ANALISIS DATA}

\section{UjiValiditasdanReliabilitas}

Hasil pengujian validitas menggunakan analisis faktor. Hasil perhitungan uji validitas pada masing-masing variabel penelitian diketahui nilai KMO diatas 0,50 sehingga kecakupan sampel terpenuhi. Selain itu nilai component matrix masing-masing indikator yang membentuk variabel penelitianlebih dari 0,4 sehingga dapat dikatakan bahwa indikator tersebut semuanya valid.

Tabel 2

Hasil Uji Validitas

\begin{tabular}{|l|c|c|c|c|}
\hline \multicolumn{1}{|c|}{ Variabel } & Nilai & Indikator & Nilai Component Matrik & Keterangan \\
\hline Kualitas Produk & 0,760 & X1.1 & 0,816 & \\
& & X1.2 & 0,813 & Valid \\
& & X1.3 & 0,762 & Valid \\
& & X1.4 & 0,781 & Valid \\
& & X1.5 & 0,599 & Valid \\
& & X1.6 & 0,681 & Valid \\
& & X1.7 & 0,489 & Valid \\
\hline Citra Merek & 0,699 & X2_1 & 0,839 & Valid \\
& & X2_2 & 0,874 & Valid \\
& & X2_3 & 0,821 & Valid \\
\hline Persepsi Harga & 0,704 & X3_1 & 0,866 & Valid \\
\cline { 3 - 5 } & & X3_2 & 0,821 & Valid \\
& & X3_3 & 0,848 & Valid \\
\hline Proses & 0,777 & Y1 & 0,839 & Valid \\
\hline Keputusan & & Y2 & 0,862 & Valid \\
Pembelian & & Y3 & 0,827 & Valid \\
& & Y4 & 0,816 & Valid \\
\hline
\end{tabular}


Nurul Fatmawati. A

Euis Soliha

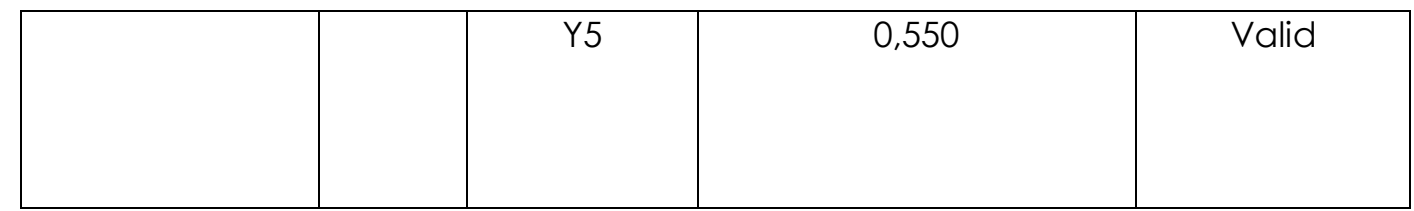

Sumber : data primer yang diolah, 2016

Hasil pengujian reliabilitas variabel citra merek, kualitas produk, persepsi harga dan keputusan pembelian memiliki nilai alpha cronbach lebih dari 0,7 sehingga variabel citra merek, kualitas produk, persepsi harga dan proses keputusan pembelian reliabel.

Tabel 3

Pengujian Reliabilitas

\begin{tabular}{|c|c|c|c|}
\hline Variabel & $\alpha$ cronbach & $\alpha$ standar & Keterangan \\
\hline Kualitas Produk & 0,828 & 0,7 & Reliabel \\
Citra Merek & 0,793 & 0,7 & Reliabel \\
Persepsi Harga & 0,783 & 0,7 & Reliabel \\
Proses Keputusan Pembelian & 0,841 & 0,7 & Reliabel \\
\hline
\end{tabular}

Sumber : data primer yang diolah, 2016

\section{Regresi Linear Berganda}

Analisis regresi linear berganda digunakan untuk menguji adanya pengaruh variabelbebas terhadap variabel terikatdapat dilihat dalam tabel sebagai berikut:

Tabel 4

Hasil Analisis Regresi

\begin{tabular}{|l|c|c|c|}
\hline \multicolumn{1}{|c|}{ Variabel } & $\begin{array}{c}\text { Standardized } \\
\text { Coefficients }\end{array}$ & $\mathbf{t}$ test & Tingkat Signifikan (P-value) \\
\hline Kualitas Produk & 0,379 & 5,534 & 0,000 \\
Citra Merek & 0,534 & 8,227 & 0,000 \\
Persepsi Harga & 0,180 & 2,651 & 0,009 \\
\hline Fhit & & 50,852 \\
Fsig & & 0,000 \\
Adjusted R2 & & 0,602 \\
\hline
\end{tabular}

Sumber : data primer yang diolah, 2016

Berdasarkan analisis regresi di atas, maka dapat diketahui variabel yang paling dominan dalam mempengaruhi proses keputusan pembelian adalah citra merek dengan koefisien regresi tertinggi sebesar 0,534; diikuti kualitas produk dengan koefisien regresi sebesar 0,379 dan persepsi harga dengan koefisien regresi sebesar 0,180 


\section{Koefisien Determinasi}

Nilai adjusted $R$ square adalah 0,602. Hal ini berarti 60,2 persen variasi proses keputusan pembelian konsumen dapat dijelaskan oleh variasi dari ketiga variabel independen (kualitas produk $\left(X_{1}\right)$, citra merek $\left(X_{2}\right)$ dan persepsi harga $\left.\left(X_{3}\right)\right)$. Sedangkan sisanya 39,8 persen $(100 \%$ $60,2=39,8 \%$ ) dijelaskan oleh sebab-sebab yang lain, misalnya promosi.

\section{Uji F}

Uji F digunakan untuk menguji goodness of fit atau kelayakan dari model regresi, yaitu apakah model yang digunakan dalam penelitian layak (fit) atau tidak. Model dikatakan fit jika nilai signifikansi kurang dari 0,05 (Ghozali, 2011).Uji F pada dasarnya mirip dengan koefisien determinasi yang juga di pakai untuk menilai kebaikan model. Tabel 4.10 hasil dari F hitung sebesar 50,852dengan tingkat signifikan 0,000 kurang dari 0,05, maka model regresi layak digunakan. Ataudiartikanbahwakualitas produk, citra merek dan persepsi hargasecarasimultan/bersama-samaberpengaruhterhadapproses keputusan pembelian konsumen.

\section{Pengujian Hipotesis}

Pada Tabel 4 dapat diketahui bahwa kualitas produk diperoleh nilai † hitung sebesar 5,534 lebih besar dari $\dagger$ tabel 1,66 dengan nilai signifikansi sebesar 0,000 kurang dari 0,05, sehingga hipotesis yang menyatakan bahwa kualitas produk berpengaruh positif terhadap proses keputusan pembelian dapat diterima atau terbukti kebenarannya. Semakin baik kualitas produk, maka proses keputusan pembelian akan semakin meningkat

Pada Tabel 4.10 dapat diketahui bahwa citra merek diperoleh nilai t hitung sebesar 8,227 lebih besar dari $\dagger$ tabel 1,66 dengan nilai signifikansi sebesar 0,000 kurang dari 0,05, sehingga hipotesis yang menyatakan bahwa citra merek berpengaruh positif terhadap proses keputusan pembelian dapat diterima atau terbukti kebenarannya. Semakin baik citra merek, maka proses keputusan pembelian akan semakin meningkat

Pada Tabel 4.10 dapat diketahui bahwa persepsi harga diperoleh nilai thitung sebesar 2,651 lebih besar dari $\dagger$ tabel 1,66 dengan nilai signifikansi sebesar 0,009 kurang dari 0,05, sehingga 


\section{Nurul Fatmawati. A \\ Euis Soliha}

hipotesis yang menyatakan bahwa persepsi harga berpengaruh positif terhadap proses keputusan pembelian dapat diterima atau terbukti kebenarannya. Semakin baik persepsi harga, maka proses keputusan pembelian akan semakin meningkat

\section{PEMBAHASAN DAN SIMPULAN}

\section{Pembahasan}

Hipotesis pertama diterima yaitu kualitas produk berpengaruh positif terhadap proses keputusan pembelian. Semakin baik kualitas produk, maka akan meningkatkan proses keputusan pembelian. Kualitas Produk menurut Feignbaum (2000: 12) bahwa kualitas produk adalah keseluruhan gabungan karakteristik barang dan jasa dari pemasaran, rekayasa, pembuatan dan pemeliharaan yang memuat produk dan jasa yang digunakan memenuhi harapan pelanggan kualitas produk terhadap keputusan pembelian. Karena semakin tinggi kualitas produk maka konsumen akan mengambil keputusan pembelian.

Penelitian ini sejalan dengan penelitian dilakukan oleh Iryanita dan Sugiarto (2013), Saidani (2013) menyimpulkan bahwa variabel kualitas produk berpengaruh positif terhadap keputusan pembelian.

Hipotesis kedua diterima yaitu citra merek berpengaruh positif terhadap proses keputusan pembelian. Semakin baik citra merek, maka akan meningkatkan proses keputusan pembelian. Brand image atau brand description, yakni deskripsi tentang asosiasi dan keyakinan terhadap merek tertentu. Brand Image dapat dianggap sebagai jenis asosiasi yang muncul dalam benak konsumen ketika mengingat suatu merek tertentu. Asosiasi itu dapat muncul dalam bentuk citra atau pemikiran tertentu yang dikaitkan dengan suatu merek (Tjiptono, 2005: 49).

Brand image yang positif akan membuat konsumen menyukai suatu produk dengan merek yang bersangkutan dikemudian hari, sedangkan bagi produsen brand image yang baik akan membantu kegiatan perusahaan dalam bidang pemasaran, maka dari itu, selain memperhatikan atribut fisik dari produknya,tugas perusahaan adalah membangun citra 
merek yang positif agar tingkat permintaan pembelian terhadap produknya terus meningkat.

Penelitian ini sejalan dengan penelitian dilakukan oleh Iryanita dan Sugiarto (2013) Adrianto (2013) menyimpulkan bahwa variabel citra merek berpengaruh positif terhadap keputusan pembelian. Hal ini menunjukkan bahwa reputasi yang baik mampu meningkatkan sikap konsumen dalam keputusan pembelian.

Hipotesis ketiga diterima yaitu persepsi harga berpengaruh positif terhadap proses keputusan pembelian. Semakin menarik persepsi harga yang ditawarkan, maka akan meningkatkan proses keputusan pembelian. Paul Peter dan Jerry Olson (2008) menyatakan: Persepsi harga berkaitan dengan bagaimana informasi harga dipahami seluruhnya oleh konsumen dan memberikan makna yang dalam bagi mereka. Pada saat konsumen melakukan evaluasi dan penelitian terhadap harga dari suatu produk sangat dipengaruhi oleh perilaku dari konsumen itu sendiri.

Persepsi harga sering kali menjadi sasaran investigasi dalam suatu penelitian, dibandingkan dengan objective price. Sebab, konsumen biasanya tidak mengevaluasi harga pasti (exact price) dari suatu produk ketika hendak melakukan pembelian, namun mereka mempersepsikan harga produk tersebut sebagai suatu harga yang murah, masuk akal (reasonable), atau mahal berdasarkan internal reference price mereka (Zeithaml 1988). Semakin baik persepsi konsumen terhadap harga, maka akan meningkatkan keputusan pembelian. Penelitian ini sejalan dengan penelitian dilakukan oleh Iryanita dan Sugiarto, menyimpulkan bahwa persepsi harga berpengaruh positif terhadap keputusan pembelian.

\section{Simpulan}

a. Kualitas produk berpengaruh positif terhadap proses keputusan pembelian. Semakin baik kualitas produk, maka akan meningkatkan proses keputusan pembelian.

b. Citra merek berpengaruh positif terhadap proses keputusan pembelian. Semakin baik citra merek, maka akan meningkatkan proses keputusan pembelian.

c. Persepsi harga berpengaruh positif terhadap proses keputusan pembelian. Semakin menarik persepsi harga yang ditawarkan, maka akan meningkatkan proses keputusan pembelian. 
Nurul Fatmawati. A

Euis Soliha

\section{IMPLIKASI DAN KETERBATASAN}

Implikasi

a. Pada kualitas produk perusahaan motor Honda perlu memperhatikan fitur sepeda motor matic Honda.

b. Pada citra merek perlu meningkatkan ketertarikan, dimana menurut persepsi responden masih rendah diantara item pertanyaan yang membentuk citramerek. Hal ini dapat dilakukan dengan mengadakan event, terutama di wilayah Puri Anjasmoro, sehingga masyarakat tertarik dengan produk matic yang diproduksi oleh Honda.

c. Pada persepsi harga perlu memperhatikan perbandingan harga dengan pesaing, semakin harga yang ditawarkan lebih bagus maka akan meningkatkan keputusan pembelian.

\section{Keterbatasan}

a. Keterbatasan sampel penelitian sebagai salah satu sumber data pokok, yakni terbatas hanya pada konsumen pengguna sepeda motor matic Honda di wilaayah Puri Anjasmoro.

b. Nilai adjusted R Square $\left(R^{2}\right)$ yang dihasilkan sebesar $60,2 \%$. Hal ini berarti variasi proses keputusan pembelian dapat dijelaskan oleh variasi dari ketiga variabel independen (kualitas produk, citra merek dan persepsi harga). Sedangkan sisanya 39,8 persen (100\%$60,2=39,8 \%$ ) dijelaskan oleh sebab-sebab yang lain, misalnya faktor sosial, gaya hidup.

\section{DAFTAR PUSTAKA}

Adrianto, Idris. 2013. Pengaruh Kualitas Produk, Citra Merek, Harga Dan Promosi Terhadap Keputusan Pembelian Mobil Jenis Mpv Merek Toyota Kijang Innova Di Semarang. Diponegoro Journal Of Management. Volume 2, Nomor 3, Tahun 2013, Halaman 1-10 Amirullah. 2002. PerilakuKonsumen. CetakanPertama. Penerbit. Grahallmu. Jakarta

DjarwantodanPangestuSubagyo. 2000. StatistikInduktif. EdisiKeempat. CetakanKelima. BPFE. Yogyakarta

Feigenbaum, A.V. 2000. KendaliMutuTerpadu, Jilid 1, EdisiKetiga, Erlangga, Jakarta 
Fransiska, Pramita. 2010. Analisis Pengaruh Kualitas produk dan Kualitas Layanan dan Persepsi Harga Terhadap Kepuasan Pelanggan Air Minum Kemasan. Skripsi. UniversitasDiponegoro

Ghozali, Imam. 2011. AplikasiAnalisis Multivariate Dengan Program IBM SPSS 19. Badan Penerbit Universitas Diponegoro, Semarang

Iryanita, RizkydanSugiarto. 2013. AnalisisPengaruh Citra Merek, PersepsiHarga, danPersepsiKualitasProdukTerhadapKeputusanPembelian (StudiPadaKonsumenproduk ATBM Pekalongan). Semarang :UniversitasDiponegoro. repository.undip.ac.id (diakses 21 Januari 2015 pukul 20:50 WIB)

Kotler, Philip. 2000. Manajemen Pemasaran di Indonesia: Analisis,Perencanaan, implementasi, dan pengendalian. Jakarta: Salemba Empat

Kotler, Philip dan Gary Amstrong, 2008. Prinsip-PrinsipPemasaran. Jilid 1. EdisiKeduabelas. Erlangga. Jakarta

Kotler, Philip dan Kevin Lane Keller. 2009. AlihBahasa : Benyamin Molan. ManajemenPemasaran. EdisiKetigabelas. Jilid 1. CetakanKeempat. PT. Indeks. Jakarta

Lin, Nan-Hong. 2007. The Effect of Brand Image and Product Knowledge on Purchase Intention Moderated by Price Discount. Journal of International Management Studies. Tatung University, Taiwan

Machfoedz, Mahmud. 2005. Kewirausahaan :Metode, Manajemen, danlmplementasi.Yogyakarta : BPFE - Yogyakarta

Oentoro, Deliyanti. 2010. ManajemenPemasaran Modern. Yogyakarta: LaksbangPressindo.

Peter, J. Paul and Jerry C. Olson. 2008. Consumer Behavior : Perilaku Konsumen dan Strategi Pemasaran. Cetakan Pertama Edisi Bahasa Indonesia. Penerbit Erlangga. Jakarta.

Purwati, Setiawan, Rohmati. 2012. Pengaruh Harga Dan Kualitas Produk Terhadap Keputusan Pembelian Motor Honda Matic Beat. Jurnal Ekonomi dan Informasi Akuntansi (Jenius).Vol. 2 No. 3 Sept 2012

Saidani. 2013. Pengaruh Kualitas Produk Dan Disain Produk Terhadap Keputusan Pembelian Sepatu Olahraga Futsal Adidas Di Jakarta Timur. Jurnal Riset Manajemen Sains Indonesia (JRMSI). Vol. 4, No. 2, 2013

Setiadi, Nugroho J. 2003, Perilaku Konsumen. Kencana. Jakarta

Shimp, Terence. 2003. Periklanan Promosi \& Aspek Tambahan Komunikasi Pemasaran Terpadu, Jilid I ( edisi 5), Jakarta Erlangga.

Stanton, William J. 2004. PrinsipPemasaran (terjemahan). Erlangga. Jakarta.

Sugiyono. 2010. MetodepenelitianKuantitatifKualitatifdan R\&D, Penerbit ALFABETA

Suryani, Tatik. 2013. PerilakuKonsumen di Era Internet :Implikasinya pada Strategi Pemasaran. EdisiPertama. Grahallmu. Yogyakarta.

Sutisna, 2003, Perilaku Konsumen \& Komunikasi Pemasaran, Remaja Rosdakarya, Bandung 


\section{Nurul Fatmawati. A}

\section{Euis Soliha}

Swasta, Basu dan Sukotjo, Ibnu W. 2000. Pengantar Bisnis Modern. Yogyakarta:BPFE

Swastha, Basu, danlrawan. 2000. ManajemenPemasaran Modern, EdisiKeduaCetakanKesebelas, Liberty Offset, Yogyakarta

Tjiptono, Fandy. 1999. StrategiPemasaran. Yogyakarta: Cetakanketiga, Andi.

Tjiptono, Fandy. 2005. Pemasaran Jasa, Malang: Bayumedia Publishing

Tjiptono, Fandy. 2006.Manajemen Pelayanan Jasa. Penerbit Andi. Yogyakarta

Tjiptono, Fandy. 2008. Strategi Pemasaran. Edisi III. Andi. Yogyakarta.

Zeithaml, V. A., 1988, Consumer Perception of Price, Quality, and Valve: a Means-end Model and Synthesis of Evidence, Journal of Marketing, 52, pp. 2-1 1

Evelina,Handoyo, Listyorini 2012.Pengaruh Ekuitas Merek, Kualitas Produk Dan Harga Dan Promosi Terhadap Keputusan Pembelian Kartu Perdana TELKOM FLEXI 